\title{
The effect of passive immunization against oestrogens on the onset of parturition in the ewe
}

\author{
N. C. Rawlings*, H. C. Pant $\dagger$ and W. R. Ward \\ Department of Veterinary Clinical Studies, University of Liverpool, Leahurst, \\ Neston, Wirral, Merseyside L64 7TE, U.K.
}

\begin{abstract}
Summary. Six ewes were treated twice daily with intravenous injections of antiserum to oestrogens and 3 ewes received normal sheep serum from Day 140 of gestation until parturition. All 9 ewes experienced normal parturitions and produced healthy active lambs after similar gestation lengths. Progesterone and prostaglandin F concentrations in maternal jugular venous plasma were similar in the immunized and control ewes, but total unconjugated oestrogen concentrations were significantly higher in the immunized ewes $(P<0.005)$. It is concluded that immunization of the ewe against total unconjugated oestrogens did not affect the normal occurrence of parturition.
\end{abstract}

\section{Introduction}

The ability of oestrogen to stimulate uterine activity has long been known (see Finn \& Porter, 1975) and intramuscular injections of oestrogens can induce parturition in the ewe (Delouis \& Terqui, 1974). Before parturition there is a sharp increase in circulating unconjugated oestrogens in the maternal (Challis, 1971; Rawlings \& Ward, 1976) and fetal (Rawlings \& Ward, 1978) circulation in sheep. At term, uterine activity and circulating oestrogen concentrations are positively correlated (Rawlings \& Ward, 1978) and the temporal pattern of circulating oestrogen concentrations is reflected by myometrial oestrogen concentrations (Rawlings \& Ward, 1976). However, although the endocrine changes at parturition induced by the infusion of glucocorticoids and adrenocorticotrophin to the intact fetal lamb are similar to those at term (Thorburn, Challis \& Robinson, 1977), it has been suggested that the pre-partum rise in oestrogen level is not essential for parturition. This premise was based on the apparent absence of an increase in maternal plasma concentrations of oestrogen when parturition was induced by adrenocorticotrophin treatment of the hypophysectomized ovine fetus (Kendall et al., 1977).

The purpose of the present experiment was to investigate the effect of reducing the maternal plasma levels of unconjugated oestrogens on the onset of parturition in the ewe.

\section{Materials and Methods}

\section{Antisera and immunization treatments}

Antisera against an oestradiol-17 $\beta$ hemisuccinate-bovine serum albumin conjugate were raised in 6 cyclic ewes. The ewes were injected intramuscularly with 1-4 mg of the conjugate in $1 \mathrm{ml}$ of an emulsion of saline $(0.9 \%, \mathrm{w} / \mathrm{v}, \mathrm{NaCl})$ and Freund's complete adjuvant (Difco, Detroit). Injections were given at monthly intervals and the ewes were bled by jugular venepuncture with a sterile procedure 10-15 days after each injection. Serum from each ewe was stored separately at $-15^{\circ} \mathrm{C}$ until tested for titre and cross-reactions, or used for passive immunization.

From Day 140 of pregnancy until term, 6 ewes received twice daily intravenous injections of 10-20 $\mathrm{ml}$ of one of the antisera and 3 animals received equivalent volumes of normal serum from an anoestrous ewe. Blood samples were taken before each treatment. The volume of antiserum

\footnotetext{
* Present address: Department of Veterinary Physiological Sciences, Western College of Veterinary Medicine, University of Saskatchewan, Saskatoon, Saskatchewan, Canada S7N OWO.

‡ Present address: Department of Obstetrics \& Gynaecology, Veterinary College, P.O. Mathura (U.P.), India.
} 
required for each injection was calculated from the ability of the antiserum to bind $\left[2,4,6,7(\mathrm{n}){ }^{3} \mathrm{H}\right]-$ oestradiol-17 $\beta$ in vitro and available estimates of daily production rates of oestradiol-17 $\beta$ and oestrone in the late pregnant ewe (Bedford, Challis, Harrison \& Heap, 1972). The amount of antiserum administered was estimated to be far in excess of that required to bind, at $50 \%$ saturation, the quantities of unconjugated oestrone and oestradiol-17 $\beta$ present in the maternal circulation, e.g. because oestrogen production rises dramatically just before term, a greater volume of antiserum with a high titre was used from Day 143 . Because the antisera cross-reacted with oestrone (68\%) and oestradiol$17 \alpha(55 \%)$, they are referred to as anti-oestrogen antisera. The comparative titres and cross-reactions of the antisera and the antibody titres created in the passively immunized sheep were estimated in the in-vitro liquid radioimmunoassay system referred to below. Results are expressed for $100 \mu l$ aliquots, at a dilution of $1: 10000$ or $1: 1000$, with $17 \mathrm{pg}\left[2,4,6,7(\mathrm{n})^{3} \mathrm{H}\right]$ oestradiol-17 $\beta$ added to each assay tube.

\section{Hormone assays}

Plasma samples were analysed for progesterone, total unconjugated oestrogens and prostaglandin (PG) F concentrations by established radioimmunoassays using specific antisera after solvent extraction from plasma (Rawlings \& Ward, 1978). All estimations were made in duplicate and corrected for procedural losses. Percentage cross-reactions were estimated by the method of Abraham, Odell, Edwards \& Purdy (1970). Assay sensitivity was regarded as the smallest quantity of unlabelled hormone capable of significantly displacing labelled hormone from the antiserum.

Total unconjugated oestrogens. The antiserum was raised against an oestradiol-17ß-protein conjugate and had a $50 \%$ cross-reaction with oestrone, $38 \%$ with oestradiol- $17 \alpha, 24 \%$ with oestriol and $<0.1 \%$ with all non-oestrogenic steroids tested. The results are therefore expressed in terms of total unconjugated oestrogens. The percentage extraction $(81 \cdot 52 \pm 0.68 \%, n=162)$ of oestradiol$17 \beta$ from plasma of the 6 immunized ewes was similar to that from plasma of the 3 untreated ewes. The assay sensitivity was $5 \mathrm{pg} /$ tube $(n=30)$ and the inter-assay coefficient of variation was $16.08 \pm$ 0.86 (s.e.m.) \% $(n=92)$. When $20(n=27), 50(n=50)$ or $100(n=9)$ pg oestradiol-17 $\beta$ were added to plasma from cyclic ewes, the values obtained were $22 \pm 1,49 \pm 1$ and $89 \pm 4 \mathrm{pg}$, respectively.

Progesterone. The progesterone antiserum showed a $20 \%$ cross-reaction with $17 \alpha$-hydroxyprogesterone, $6 \%$ with 21 -hydroxyprogesterone, $1 \%$ with $20 \alpha$-dihydroprogesterone, $0.5 \%$ with testosterone, $0.6 \%$ with dehydroepiandrosterone and $<0.1 \%$ with other steroids tested. The sensitivity of the assay was $10 \mathrm{pg} /$ tube $(n=30)$ and the interassay coefficient of variation was $17 \cdot 22 \pm$ $2.01 \%(n=37)$. When progesterone was added to plasma at $50(n=7), 100(n=11)$ and $500(n=10)$ $\mathrm{pg}$, the corresponding values obtained were $68 \pm 11,119 \pm 11$ and $451 \pm 17 \mathrm{pg}$.

$P G F$. The antiserum was raised against a PGF-2 $\alpha$-protein conjugate and showed a $32.6 \%$ cross-reaction with PGF-1 $\alpha$ and $<0.58 \%$ with all other PGs tested (PGE-2, 0.58\%; PGE-1, 0.43\%; PGA-2, 0.05\%; PGA-1, 0.01\%; PGB-2, 0.01\%; PGB-1, 0.008\%; 15-keto-PGF-2 $\alpha, 0.2 \% ; 15-$ keto-PGE-2, $0.17 \%$ ): the results are therefore expressed in terms of PGF (tromethamine salt). The water blank was $3 \pm 2 \cdot 17 \mathrm{pg}(n=10)$ and the assay sensitivity, regarded as the water blank value plus twice its standard deviation, was therefore $10.52 \mathrm{pg} /$ tube. The interassay coefficient of variation was $15 \cdot 88 \pm 7 \cdot 54 \%(n=10)$, and estimates of $16.6 \pm 3.4,49 \cdot 4 \pm 0.3$ and $78.3 \pm 1.4 \mathrm{pg}$ PGF $(n=3)$ were obtained for added amounts of 20,50 and 100 pg PGF-2 $\alpha$.

\section{Results}

All 9 ewes had normal parturitions and produced healthy active lambs after a mean \pm s.e.m. gestation length of $146.67 \pm 0.56$ days ( 6 treated ewes) and $145.00 \pm 1.53$ days ( 3 untreated ewes). These means were not significantly different. The patterns of progesterone and PGF concentrations in jugular plasma (Table 1) did not differ, but the concentrations of oestrogen were very different after treatment had started $(P<0.005)$. The percentage binding by plasma of control ewes, and preimmunization samples from treated ewes, never exceeded $4 \%$, a figure similar to the level of non-specific binding normally observed in the liquid radioimmunoassay system employed. However, the binding capacity of plasma from the immunized ewes increased, over the period of treatment, especially following the increased dose after Day 143 of gestation. 


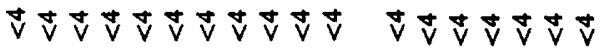

$\stackrel{\widehat{v}}{\dot{v}}$

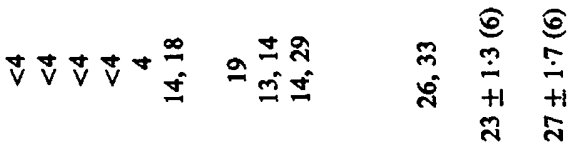

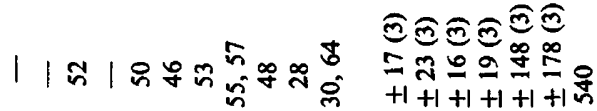

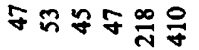

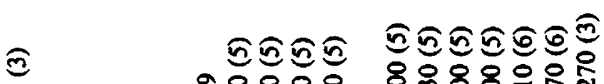

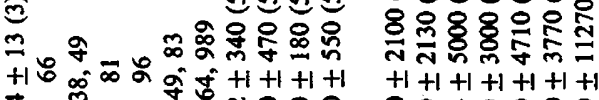

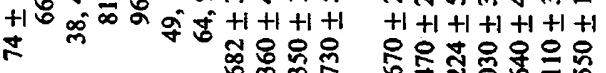

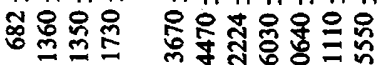

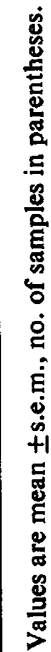

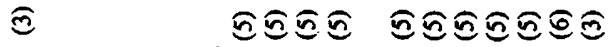

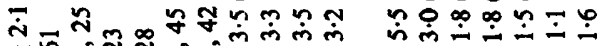

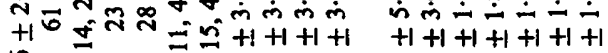

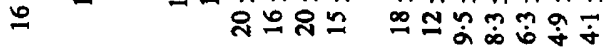

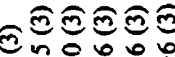

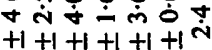

$2 \dot{\alpha}=\stackrel{\sim}{\sim} \stackrel{\infty}{\dot{0}}$

| $\mid$ 突

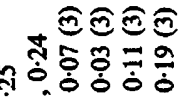

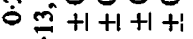

䒹

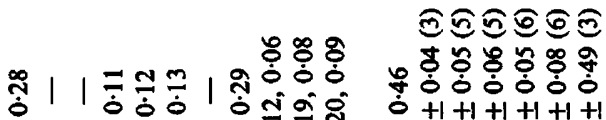

$0+1+1+1+1+1+1$

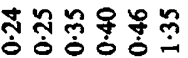

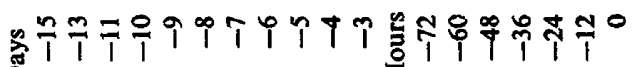




\section{Discussion}

Ferin, Raziano, Tempone \& Vandewiele (1970) have demonstrated that passive immunization of rats with an antiserum raised against oestradiol-17 $\beta$ will effectively neutralize the biological activity of endogenous and exogenous oestrogens. Caldwell, Scaramuzzi, Tillson \& Thorneycroft (1970) were able to block cyclic activity in ewes by actively immunizing them against oestradiol-17 . In the present study, immunization of the preparturient ewe against unconjugated oestrogens had no effect on parturition, although there was a massive rise in total unconjugated oestrogen concentrations in the plasma of the treated ewes. It is presumed that the anti-oestrogen sera bound circulating unconjugated oestrogens with such high affinity as to prevent hepatic removal, metabolism and conjugation.

Although plasma ether-extractable oestrogen concentrations rose in parallel with antisera titre, the calculated dose of antisera was sufficient to neutralize unconjugated oestrogens far in excess of their calculated production rates: $100 \mu$ l aliquots of 1:1000 dilutions of plasma from passively immunized ewes bound $27 \%$ of $17 \mathrm{pg}$ labelled oestradiol-17 $\beta$ at term, indicating spare antibody capacity even at this time.

Because immunization against oestrogens is usually able to block known oestrogen-dependent events and because there was a surfeit of antibodies in the plasma of the passively immunized ewes in the present study, it is suggested that unconjugated oestrogens in the maternal blood compartment are not involved in the initiation of parturition in the ewe and that any effect of placental unconjugated oestrogen on the myometrium probably involves a local tissue transfer. Oestrogen is produced primarily by the placenta during pregnancy in the ewe, and conjugated as well as unconjugated oestrogens are secreted (Pierrepoint, Anderson, Harvey, Turnbull \& Griffiths, 1971). Oestradiol-17 $\beta$ (Challis, Harrison \& Heap, 1973) and oestrone (Findlay \& Seamark, 1973) are rapidly and extensively conjugated after intravenous injection into the pregnant ewe (67-74\% and $76 \%$ respectively). Oestrogen sulphates may have oestrogenic effects on the uterus (Pierrepoint et al., 1971), but in the ovariectomized ewe oestradiol benzoate appears to be 20 times more effective in stimulating uterine motility than oestrone sulphate (unpublished results of J. Prud'Homme, cited by Bosc, Delouis \& Terqui, 1977). The present experiment investigated only the involvement of unconjugated oestrogens in the maternal circulation and the antisera used would probably not have bound any oestrogen conjugates (Boilert, Edqvist, Johannson, Lindberg \& Martinsson, 1973).

We thank Dr B. V. Caldwell (Yale University, U.S.A.) for the oestrogen antiserum used in the radioimmunoassay; Dr B. J. A. Furr (N.I.R.D., Reading) for the progesterone antiserum; Dr S. C. Sharma (University of Liverpool) for the PGF-2 $\alpha$ antiserum; Dr J. Pike, Upjohn Company, for the PGF-2 $\alpha$ tromethamine salt; and Mrs S. M. Midmer for assistance with the progesterone and PG assays. The work was supported in part by a grant from the Medical Research Council.

\section{References}

Abraham, G.E., Odell, W.D., Edwards, R. \& Purdy, J.M. (1970) Solid-phase radioimmunoassay of oestrogens in biological fluids. Acta endocr., Copenh., Suppl. 147, 332-346.

Bedford, C.A., Challis, J.R.G., Harrison, F.A. \& HeAP, R.B. (1972) The role of oestrogens and progesterone in the onset of parturition in various species. J. Reprod. Fert., Suppl. 16, 1-23.

Bollert, B., EdQvist, L.E., JohanNSON, E.D.B., LindBerg, P. \& MARTInsson, K. (1973) The influence of conjugated estrogens in radioimmunoassays using different antibodies against estradiol-17 $\beta$. Steroids 22, 891-894.

Bosc, M.J., De Louis, C. \& Terqui, M. (1977) Control of the time of parturition of sheep and goat. In Proc. Am. Soc. Anim. Sci. University of Wisconsin, pp. 89-100. [Symp. on Management of Reproduction in Sheep and Goats.]

Caldwell, B.V., Scaramuzzi, R.J., Tillson, S.A. \& ThORNEYCROFT, I.H. (1970) Physiological studies using antibodies to steroids. In Immunologic Methods in Steroid Determination, pp. 183-197. Eds F. G. Peron \& B. V. Caldwell. Appleton Century Crofts, New York.

Challis, J.R.G. (1971) Sharp increase in free circulating oestrogen immediately before parturition in sheep. Nature, Lond. 229, 208.

Challis, J.R.G., Harrison, F.A. \& Heap, R.B. (1973) The kinetics of oestradiol-17及 metabolism in the sheep. $J$. Endocr. 57, 97-110.

De Louis, C. \& Terqui, M. (1974) Augmentation de la production laitiére par un apport exogéne d'oestra- 
diol 17-beta en fin de gestation chez la brebis. $C$. $r$. hebd. Séanc. Acad. Sci., Paris D 278, 307-310.

Ferin, M., Raziano, J., Tempone, A. \& Vandewiele, R.L. (1970) The use of antibodies as a tool in studies of reproductive physiology. In Immunologic Methods in Steroid Determination, pp. 199-214. Eds F. G. Peron \& B. V. Caldwell. Appleton Century Crofts, New York.

Findlay, J.K. \& SeamaRK, R.F. (1973) The occurrence and metabolism of oestrogens in the sheep foetus and placenta. In The Endocrinology of Pregnancy and Parturition-Experimental Studies in the Sheep, pp. 54-64. Ed. C. G. Pierrepoint. Alpha Omega Alpha, Cardiff.

FinN, C.A. \& Porter, D.G. (1975) The Uterus. Elek Science, London.

Kendall, J.Z., Challis, J.R.G., Harts, I.C., Jones, C.T., MITChEll, M.D., RITChie, J.W.K., Robinson, J.S. \& ThorbuRN, G.D. (1977) Steroid and prostaglandin concentrations in the plasma of pregnant ewes during infusion of adrenocorticotrophin or dexamethasone to intact or hypophysectomised foetuses. J. Endocr. 75, 59-71.

Pierrepoint, C.G., Anderson, A.B.M., Harvey, G., Turnbull, A.D. \& Griffiths, K. (1971) The conversion of $\mathrm{C} 19$ steroids to oestrogen sulphates by the sheep placenta. J. Endocr. 50, 537-538.

RAwlings, N.C. \& WARD, W.R. (1976) Changes in steroid hormones in plasma and myometrium and uterine activity in ewes during late pregnancy and parturition. J. Reprod. Fert. 48, 355-360.

RaWlings, N.C. \& WARD, W.R. (1978) Correlations of maternal and fetal endocrine events with uterine pressure changes around parturition in the ewe. J. Reprod. Fert. 54, 1-8.

Thorburn, G.D., Challis, J.R.C. \& Robinson, J.S. (1977) Endocrine control of parturition. In The Biology of the Uterus, pp. 653-732. Ed. R. Wynn. Plenum Press, New York.

Received 28 March 1978 